\title{
CHALLENGES OF THE ALBANIAN LANGUAGE IN THE INTERNET ERA
}

\author{
Luljeta Adili- Çeliku \\ Docent, University Ss. Cyril and Methodius, Skopje, North Macedonia \\ l.adili@flf.ukim.edu.mk \\ Meral Shehabi-Veseli \\ Docent, South East European University, Tetovo, North Macedonia \\ m.shehabi@seeu.edu.mk
}

\begin{abstract}
Language is a live organism and as every other living being develops and is enriched with new words and terms, which enter the life of society together with the new tool, i.e. they enter in and mix with the order of Albanian words. Such a thing is inevitable and in some cases even useful, but every word that is lined up in the order of Albanian words must be well filtered. "The introduction of new words and exclusion of old ones is a natural process, and it happens in any language. This is what happened with the Greek borrowings in Latin, with the Arabic borrowings in Greek, with the Latin borrowings in many European languages, with the Persian borrowings in Turkish, with the Turkish borrowings in Albanian, etc." - Prof. Hajri Shehu emphasizes in a scientific interview (Shehu, 2017). In recent decades, with the expansion of the Internet, many foreign words began to enter and be used in the Albanian language. English took up more space than expected; in addition to penetrating through various tool notions, it also replaced centuries-old native words of Albanian.

The paper has been divided into three parts and in each part an issue has been dealt with: the first part talks about the use of foreign words and the existing words in Albanian; the second part deals with the use of emoticons used instead of words and the third part deals with writing errors in the Albanian language. These are some of the issues that have created a great
\end{abstract}


concern for the Albanian language in this century and they certainly need to be addressed seriously to prevent the dangers that may threaten it.

Keywords: foreign words, language threats, Internet era, emoticons, spelling/writing errors.

\section{Hypotheses:}

1. The Albanian language is very exposed to foreign words and they pose a serious risk for its alienation in the lexical field.

2. The Albanian language is written with many spelling mistakes on social networks.

\section{INTRODUCTION}

To talk about the Albanian language means to speak about one of the oldest languages in the world, which has faced many challenges over the years and has come rich and beautiful to this day. In the age of the Internet, it is being suffocated on daily bases by a latent war that is threatening it, as well as several other languages in the world. This is a confrontation with the world of the Internet, with the language of the Internet, which is endangering it to the point of alienation, not to say to the dismantling of its lexicon, to the change of its grammatical structure and to the disappearance of some of its grammatical categories.

When we refer to the language of the internet, we imply: the use of global language such as English instead of one's' mother tongue even when not appropriate, the language of icons, which has been replacing real language words and the deterioration of standard Albanian by writing it inappropriately and with many errors, because everyone is given the opportunity to write and comment publicly without filtering these messages by any means. These are some of the most worrying issues related to the future of the Albanian language.

English has already been confirmed as the global lingua franca. It is spoken and heard in almost every home, especially by the younger generations, who speak it in parallel with their mother tongue. We are also exposed to this language through technological means which include the names of those means too. The Albanian language must accept and use words and objects as they come after penetrating through different ways. Linguists and researchers in the field of informatics have been trying to find some Albanian equivalent words by adapting it to the tool, but this has remained only an effort as we rarely or hardly ever use these notions in the Albanian language.

The reasons behind this on the one hand are numerous; on the other hand, they are also unforgivable. The former happens because the Albanian language will certainly keep in step with latest developments and will become part of the world of technology. This happens 
whether we like it or not but, what is unforgivable is the use of foreign words even instead of those words that already exist in the Albanian language as such. This reflects irresponsibility and unawareness of the misfortune we are causing to it. The year 2005 was the year when important steps were undertaken for the realization of projects and the compilation of electronic dictionaries; the work for the adaptation of the Albanian language to the era of the Internet has been going on since then.

Also, the Microsoft suite in the Albanian language began to be adapted in order to help those who cannot speak and write in English well, but still have to use a computer. The adaptation of languages installed in smart phones also began to take place.

There have been 16 years since these steps of the adaptation of the Albanian language to the world of the Internet begun, and the question now is what has indeed been achieved? What results have we got for the new generations? Have we managed to teach them the pure Albanian language without introducing foreign words? Have we managed to raise their awareness of the use and preservation of the language? Of course, such a thing remains only to be desired as insufficient efforts have been made in primary and secondary schools and universities with regard to this issue. This transition period we are living in where everything is changing at a rapid pace has alienated everyone's way of life and has certainly affected the language, as language is related to humans and their lives. Large movements, the rapid dissemination of information, establishing contacts with different languages, the swift development of technology has made small languages find themselves in a state of shock, failing to install filters in order to be able to preserve them.

This is a great concern for linguists and for all those who fanatically love language and nation. Activities related to various conferences for the purpose of raising the awareness for the protection of our linguistic wealth, the compilation of electronic dictionaries, of AlbanianEnglish dictionaries of informatics, trying to find and adapt Albanian words for computer terminology have been more frequent in this period, but it remains to be seen how the battles of this war will be fought in the years to come.

Several scholars have dealt with these issues, with the "trouble" that has occupied the Albanian language, including Rami Memushaj, Qemal Murati, Shefkije Islamaj, Gjovalin Shkurtaj, Xhevat Lloshi, Valter Memisha, and others. All of them have raised their voices to make the Albanian speakers aware of the preservation of the treasure they possess. "Gjuha shqipe" ('Albanian Language'), a magazine for the culture of the language, which is published 
in Kosovo, brings together linguists and their writings on the preservation and purification of the language.

Qemal Murati calls it the "English flu" that has plagued our television screens and that a new generation of English speakers is being created, which has opened many doors for employment of young people but has also closed many doors to the Albanian language, whose beautiful words are pronounced less and less frequently as time goes by. In a language article, just like this paper, he has listed a series of foreign words used on our TV/radio channels, such as: "Top Story", "Top Channel", "Fun Page", "Voice Room", and many other words and gives recommendations that journalists who speak and write the Albanian language, such as 'the Voice of America', should be followed. (Murati, 2017)

Rami Memushaj, in one of his writings, talks about the "murder of the Albanian language" for the post-'90s generations, including journalists, authors, TV speakers, etc., who have not acquired sound knowledge of the language during their schooling and therefore this "murder", as he calls it, is being committed on daily bases. (Memushaj, 2017) He points the finger at changing the way of learning the language in school curricula for the position of the Albanian language today.

Robert Schwartz raises his voice by reminding us that the passport with which we present ourselves is the language; we present ourselves through the way we speak our own language. (Shvarc, 2017) It is pure luck that the Albanian nation has survived as such and this survival has come precisely due to the preservation of the Albanian language and should continue as such, because they preserve and cohabitate with each other.

For the enrichment and preservation of the Albanian language, the renowned scholar Shefkije Islamaj has been writing all the time. She considers miserable what we are doing to our language, to ourselves with our own hands. Before becoming a standard language, the language itself was dialectical and the best from it was taken for its standardization (Islamaj, 2017). The author extinguishes the divisive rumours that language was built at the expense of one or the other dialect, but calls for using the literary form, and for preserving our mother tongue as pure as it is.

\section{Foreign words used in Albanian}

Informatics has become very important and almost impossible to function without. The terminology of this field occupies an important place in the overall lexicon of a language and 
especially in its everyday use. In order to help the users of technological tools, various explanatory dictionaries have been created, they have been adapted and pronounced, and new words have been established and created. Yet again, the Albanian language is in great trouble.

Below we have provided some foreign words that are used in Albanian, especially by pupils, students, and teachers at all levels of our educational system.

We should emphasize that for several words we have been unable to come up with an Albanian equivalent; however, even if there are several such words in Albanian, they are rarely or hardly ever used as such. These are the words we have selected in our case: Hardware (harduer), Software (softuer), Hard Disc (hard disk), Monitor (monitor), Laptop (laptop), Mouse (maus), Keyboard (tastaturë), Hard Drive (hard draiv), USB (ju-es-bi), Motherboard (madhërbord), Powerpoint (pauerpoint), Microsoft Word (uord), Windows (uindous), Microsoft Excel (eksell), Trash (trash), Inbox (inboks), Spam (spam), link (link), File (fail), Account (akaunt), Password (pasvord), CPU, Memory (memori), Printer (printer), CD (cd), Virus (virus), My Computer (kompjuteri im), Enter (enter), Space (spejs), My Documents (dokumente), Desktop (desktop), Settings (setings), Zoom (zum), Microsoft Teams (tims), Google Classroom (gugl klasrum), Chat (çet), Send (send), Draft (draft), Updates (përditësime), Compose (kompouz), Search (sërç), GPS, etj. These are just some of the many foreign words used in the Albanian language (in parentheses we have provided their pronunciation in our everyday use).

Such a number of words certainly endangers the Albanian language, and it basically comes from its ruthless users/speakers, who replace it with another language. Below we will list some of the words that can be used in the Albanian language, such as: chat - bisedoj (online chat); check-kontroll/kontrolloj; check for errors-kontrolloj për gabime; class-klasë; cleanpastroj; data object-objekt i të dhënave; compose-ndërtoj/shkruaj; send-dërgoj; trash-kosh; files- skedar; upload-ngarkoj; search-kërkoj; download-shkarkoj; settings-rregullimet; emailpostë elektronike; inbox-kuti porosish, print-shtyp, printing-shtyp, (Nebi Caka), etc. Of course, as we mentioned above, there are dictionaries in Albanian that clarify and translate translatable words.

\section{The usage of emoticons instead of words in Albanian}

It has become quite trendy nowadays to use "emojis" instead of words to express feelings and emotions. This phenomenon can be freely said to have affected all generations not just the youngsters. When writing and commenting, people find it easier to use emoticons than to write words. This language of emotions is not only prevalent on the Internet, but also on 
smartphones and other electronic devices used for interpersonal communication. Using an emoticon instead of a word takes you back in time when there were no letters and words could not be written, and the only communication between people was by using different drawings or hieroglyphs, graffiti on the walls or on stone and wood to deliver messages. Why does such a need appear in contemporary life, a kind of communication intertwined with words and emoticons?

Of course, it is easier during communication, to use an emoticon than to write words or add emotion to sentences if you use some emoticons, or the expression of emotions that we do not feel but only pretend to feel. However, such a thing does not really help language; rather their long-term use leads to loss of expression of emotions towards each other. Day by day people are becoming lazier to write and pass the language on to new generations.

There are over 722 symbols used in communication (Dorda, 2014). We will give some symbols that are used more frequently, though it is not the purpose of the paper to present their diversity. We are a lot more concerned about their use to such an extent and our message is to use words and not emoticons in our daily communication.

In order to illustrate emoticons, we are showing below some of those used more frequently in various different electronic devices: :-) (grinning face); (-) (beaming face with smiling eyes); (face with tears of joy); (rolling on the floor laughing); (smiling face with hearts), (sleepy face); (f) (face with tongue); 国(loudly crying face); (:) (grimacing face); $-($ pouting face); (birthday cake); (clinking glasses); $\bigcirc$ (loving heart); (kisses), etc.

The use of symbols and expressions certainly come as a need for faster communication, as the time we live in is dynamic and communications are more frequent through electronic means than ever before. At almost any time of the day, we communicate with each other on various applications, on social networks, etc. and symbols are used to increase the expression of emotions, but the fact of such increased use and replacement of language is quite disturbing. It would be wise to spend more time writing with each other and do this with words rather than symbols and word abbreviations.

\section{Frequent spelling errors in written Albanian language}

"Language is, indeed, our greatest asset..."-Rexhep Qosja has said, and as such, it deserves continuous attention and care, especially since we write it with lots of errors. We would not blame only the intellectuals, writers and academicians for this, who, on the contrary, are working and making constant efforts through their book publications dealing with the issue 
of spelling; yet again, the results are not satisfactory. Perhaps the finger should be pointed at print media journalists, who speak and write incorrectly without knowing how to write correctly. Most people today after graduating from university do not find time to read books, although the possibility of reading the print press is ruled out. Therefore, the journalists' responsibility for the correct writing of the language increases and is taken as a model for the others. Language is not just a means of communication; it is the sign or trace by which a nation is joined, that speaks the same language regardless of geographical boundaries.

In this paper, we will present some of the spelling mistakes that we encounter most often in the electronic media when using the Albanian language and explanations on how they should be used correctly will be given, adhering to the rules of the Albanian grammar. The goal is, by identifying those errors, to avoid them and to write our language correctly and without mistakes.

Not in vain, in the online correct spelling of Albanian they say, "Generally, reading the press in Prishtina and in Tirana (and the Albanian press in the Republic of North Macedonia) resembles listening to loud disharmonious (jangly) music in the middle of the night". This sentence encouraged us to analyse the Albanian press in general.

There are two spelling error types in a language (Memishaj, 2017): a) tongue slip or pen slip. Such a mistake is not normal in any linguistic variant. A written slogan, which circulated for a while on the media and social networking sites, was "Vota jote, zgjedhja yte!" They had used a possessive pronoun, yte that does not exist in Albanian as such at all. "Vendi jon $\ddot{\boldsymbol{e}}$ i pari në rajon!" We also have a wrong use of the gender of the possessive pronoun, instead of the correct form, which is $\boldsymbol{y} \boldsymbol{n} \ddot{\boldsymbol{e}}$.

b) Transfer of elements from one language variant (where normal) to another (e.g., from a regional dialect into a literary text, speech, or interview, etc.). Linguistically we call this a mix of register, style, etc. As long as this transfer is isolated, it is the norm. When it starts to spread, it is avoidance. If this deviation is constantly repeated, it can be taken as the norm, because often the norm is understood subjectively. And this becomes a big problem, especially in Albanian spoken on radio, television, and social networks. From here, foreign words flood our language, without being filtered at all (Albanian language: page 14). E.g., "Lançimi $i$ lajmit nga ana e tyre..." The word "lançim" is not found it in the dictionary of the Albanian language, but we hear it every day on TV or see it written in the electronic media and thus it becomes part of our life and over time it sticks to the being (spirit) of the language, which should be forbidden. Unfortunately, we can find many such foreign words. 
Of course, in this paper, it is impossible to include all the mistakes encountered in either print media or television, but we hope that the message would help in reaching our awareness. In our lectures with students, we try to achieve this by the end of the year, i.e. the awareness of language preservation, checking every word before writing it, keeping language dictionaries at hand, just for the sake of being confident while writing.

The research involved students from the South East European University - Tetovo who were engaged in tracking the electronic press and identifying and improving errors. During their very serious work, they were horrified when they saw how erroneously our language is written, without going through any proofreading procedures by specialists in the field, but rather being directly distributed to the general population. In this way, they begin to conceive mistakes as "correct" words, because their eyes are accustomed to those errors on daily bases.

\section{Reviewing of errors}

Below, we have presented, theoretically and practically, frequent mistakes that occur in the Albanian language.

We will first address some of the errors encountered when using nouns. Nouns make up the majority of the lexical fund of a language; we often encounter them written wrong in the electronic media. On various TV channels (stations/programs) we hear those words mispronounced or replaced with foreign words. The latter are easy to identify, but what endangers the Albanian language the most is the change in its syntax. Therefore, the syntactic changes that happen to a language are difficult to notice.

Noun forms, use of declension endings, plural form, use of capital letter can often be found as used in a wrong way:

a) Errors while using the definite form (article):

We hear and see on TV or radio, speakers, or writers of language, who, in some cases, have no sensitivity to how they pronounce/write the (in)definite form of the nouns. E.g. Alsat zbulon.../ për Alsati, Putin deklaron.../ për Putini .., Zaev bën hapin drejt... për Zaevi. 'Në studimet e Durham-it është përmendur...' instead of 'në studimet e Durhamit është përmendur...'

b) Errors while using cases:

It often happens that we encounter the incorrect use of cases. Our grandmothers, even those who did not attend school at all, never make such a mistake, but the 
generation of educated people makes those mistakes. This comes from the influence of the languages they speak in parallel with the Albanian. E.g. Pronari $i$ një ndërmarrje.../ instead of $i$ një ndërmarrje-je,

c) Errors while using the plural form: The plural is the Achilles heel. Here it often happens that the plural of nouns is used incorrectly.

d) Errors when using capital letters: The use of capital letters is a great concern for all Albanian language writers. This issue is problematic in terms of the names of institutions, in the field of information technology, in the field of justice, economics, etc.

Adjectives are words that stand next to nouns, depending on the gender, number, case and form of the noun. However, do we always do it right? Do we match them according to the language norm, or are we influenced by other languages by changing their position - word order? We find the adjective before the noun; we find it in disagreement with the plural form of the noun, etc. Unfortunately, we often encounter such errors, especially in groups of words of foreign origin. In addition to borrowing the word and the item, we also acquire the foreign structure - so we cause three calamities to our language by alienating it. E.g. Web faqja, we find it used in Albanian as ueb faqja instead of faqja e uebit, we should write the noun first and then the adjective, korona virus instead of virusi korona, email adresë instead of adresë elektronike, Lori kafe instead of kafe Lori, internet kafe instead of kafe interneti, simit pogaçe instead of pogaçe simiti, etj.

The verb is the grammatical category with the most spelling mistakes. Unlike nouns and adjectives that we find as foreign and misspelled words, we find verbs used in most cases in the dialectal variant, especially the verbs of the second conjugation, i.e. the irregular verbs.

The first-conjugation verbs are usually misspellt in the subjunctive form, in the present simple, third person, singular: ai të punoj, instead of të punojë, të lexoj instead of të lexojë, or the subjunctive of the thid person is confused with the present simple indicative, such as: ai të shkon instead of ai të shkojë, ai të kërkon instead of të kërkojë; then, the past simple tense, third person, singular: ai shkoj instead of ai shkoi, ai bisedoj instead of ai bisedoi, etc. The imperfect of the first conjugation in the first and second person singular, but also of the other conjugations is also confused among the Albanians of North Macedonia, such as: unë shkonja instead of unë shkoja, $t i$ shkonje instead of ti shkoje, etc. 
The second conjugation is more difficult to write correctly and without mistakes, especially the part of irregular verbs, such as: dal, marr, flas, sjell, ndjek, etc., which are quite foten used in the wrong way. As we mentioned earlier, the third-person subjunctive is also used wrongly in this conjugation, such as: ai të del instead of ai të dalë, ai të merr instead of ai të marrë, ai të foli instead of ai të flasë, etc. The participle, which is used to create compound tenses, is also found misspelled in electronic media, such as: $k a$ dalur instead of ka dalë, $k a$ marrur instead of ka marrë, ka sjellur instead of ka sjellë, etc.

The verbs of the third group also suffer the same as the two preceding groups of verbs; the groups of verbs are confused especially with those of the first conjugation, such as: unë dij instead of unë di, rrij instead of rri, etc. We find the subjunctive of the third person in the present tense as: ai të dij instead of ai të dijë, ai të vij instead of ai të vijë, etc. The participle of these verbs is also spelt incorrectly, such as: ai ka ra (see the verb bie) instead of ai ka rënë, etc.

This grammatical category is a major problem, because we quite often see it used in its incorrect form, i.e. the gender, number, form is confused. E.g., Na takoi në qytet neve, instead of Na takoi ne, or Juve ju pashë në teatër instead of Ju ju pashë, etc.

The correct use of the apostrophe in the combined (joint) forms is almost never used as required by the literary norm of the Albanian language. We do not find it spelt like $\boldsymbol{t} \boldsymbol{i}, \boldsymbol{m} \mathfrak{i}$,

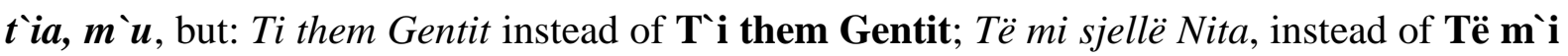
sjellë Nita; Të ja kërkojë Anës, instead of T'ia kërkojë Anës, Mos mu afro, instead of Mos m`u afro etc. Also, in most cases we mistakenly write the combined (joint) forms of the plural, such as: neve na/ juve ju - dative forms are incorrectly used for the predicative form, e.g., Neve na takoi profesori instead of Ne na takoi profesori. Atyre ju duhet shumë punë, instead of Atyre $\boldsymbol{u}$ duhet shumë punë. These mistakes are made so easily that they do not even notice it. Therefore, we decided to deal with them in order to be more vigilant about the language and how we write it, to consult Albanian grammar books, language dictionaries, both explanatory and normative, etc.

\section{CONCLUSIONS}

The issue of writing/spelling the Albanian language has been a complex issue, a concern for all linguists and language lovers. 'Small' languages are more endangered than ever before by globally spoken languages, but this should make us even more attentive and careful 
to preserve the language with the utmost care in every aspect and detail, in form and content. We should not allow its destruction and mutilation, distortion of grammar and replacement of Albanian words with foreign words. Of course, the Albanian language, like other languages in the 21 st century, will move on while being beautiful, modern and rich. This means it will continue to be enriched, to acquire new words, but not to be alienate. However, the Albanian language has many beautiful dialectal and regional words, which can become part of the standard language and for their revival, one must work hard every day. Such work for the revival of those words has been undertaken by our writer Ismail Kadare and many other writers, while it is up to us to use those words in everyday life. This should be applied by all for purposes of protecting the language.

Albanian language teachers in schools, institutions, linguists and all those who speak Albanian have important and responsible duties. It is a great responsibility to pass on the language properly to the younger generations, to the children of technology, to instil love in them to write and speak the language properly, because we have only one language. With great hope and perseverance will we will continue to contribute to the preservation of the Albanian language.

The way we speak and write the language says a lot about us, it says a lot about what we are now and what we will become in life. However, it must be emphasized that we must speak and write the language well, that is how it is preserved. We owe this to our ancestors, we owe it to all those who guarded it when it was in great danger. The Albanian language, one of the oldest languages, has come to us preserved over the centuries with many vicissitudes and as such it should be passed on to future generations.

"I escaped from the tigers

Ifed the bedbugs

I was eaten up

By the mediocrities."

- Bertolt Brecht

We will conclude this work with the saying of the sovereign of journalism, Faik Konica, who prays and says, "Oh Father who art in heaven ... Save us from the pitfalls of grammar, from the distortions of language and from the aberrations of the press!" 


\section{REFERENCES}

1. The Academy of Sciences of the Republic of Albania, 1973. Drejtshkrimi i gjuhës shqipe. Tiranë

2. The Academy of Sciences of the Republic of Albania, 1976. Fjalori drejtshkrimor $i$ gjuhës shqipe. Tiranë.

2. The Academy of Sciences of the Republic of Albania, 2004. Fjalori i gjuhës shqipe. Tiranë.

3. The Academy of Sciences of the Republic of Albania,1995. Gramatika e gjuhës shqipe I. Tiranë.

4. The Academy of Sciences of the Republic of Albania, 1995. Gramatika e gjuhës shqipe II. Tiranë.

5. Caka, Nebi \& Dika, Agni, 2005. The Academy of Sciences and Arts of the Republic of Kosovo, Fjalor i informatikës, Prishtinë.

6. Internet sources (online newspaper samples, Fol.mk, Monitori, Koha.mk, Arkivi News, Bordo, Koha.net, Globi, info shqip, Top chanel, etc.)

7. The Institute of Albanology. 2017. Gjuha shqipe, Botimi I, Prishtinë.

8. The Institute of Albanology. 2017. Gjuha shqipe, Botimi II, Prishtinë.

9. The Institute of Albanology. 2017. Gjuha shqipe, Botimi III, Prishtinë.

10. SEEU. 2014, Sociolinguistic studies II, Tetovo.

11. Shkurtaj. Gjovalin, 2008. Haw to write Albanian, Toena, Tiranë. 